\title{
Poesía fuera del cancionero: la inscripción de lo cotidiano y lo sublime
}

Poetry out of the Cancionero Book: The Inscription of the Everyday and the Sublime

https://doi.org/10.1590/1982-02672020v28d3e44

\author{
ANA MARÍA GÓMEZ-BRAVO' \\ https://orcid.org/0000-0002-4806-3882 \\ University of Washington / Seattle, Washington, Estados Unidos
}

RESUMEN: El artículo destaca la importancia de la poesía del siglo XV como vehículo comunicativo que se vale de diferentes soportes textuales para inscribir el mundo material, al que dota de significado y con el que forma un macro-signo. La conexión entre el libro y la cultura material puede verse en particular en la inscripción de edificios públicos y privados, objetos de uso cotidiano como copas y platos, así como de la indumentaria, entre la que se incluyen las joyas.

PALABRAS CLAVE: Cancionero. Cancioneiro. Cultura material. Indumentaria. Arquitectura. Joyas.

ABSTRACT: The article highlights the uses of fifteenth-century poetry on different textual supports in order to inscribe the material world and endow it with meaning, forming a macro-sign. The connection between the book and material culture can be seen in particular in the inscription of public and private buildings, objects of daily use such as cups and plates, as well as clothing and jewelry.

KEYWORDS: Cancionero. Cancioneiro. Material culture. Clothing. Architecture. Jewelry.

\begin{abstract}
1. Profesora de estudios españoles y portugueses en la Universidad de Washington en Seattle. Sus principales áreas de investigación son los estudios sobre raza y género, cultura alimentaria y estudios textuales. Su libro más reciente es Food, Texts, and Cultures in Latin America and Spain (Vanderbilt University Press 2019, coeditado). También es autora de Textual Agency: Writing Culture and Social Networks in Fifteenth-Century Spain (University of Toronto Press, 2013), Comida y cultura en el mundo bispánico (Equinox, 2017) y Repertorio métrico de la poesía cancioneril castellana del siglo XV (Universidad de Alcalá de Henares, 1998), ahora disponible en formato electrónico <http://poemetca.linhd.es>. E-mail: <agbravo@uw.edu>.
\end{abstract}


RESUMO: $\bigcirc$ artigo destaca a importância da poesia do século XV como veículo comunicativo que utiliza diferentes suportes textuais para inscrever o mundo material, o que the confere significado e forma um macrossinal. A conexão entre o livro e a cultura material pode ser vista, em particular, na inscrição de edifícios públicos e privados, objetos de uso diário, como xícaras e pratos, além de roupas, incluindo jóias.

PALAVRAS-CHAVE: Cancionero. Cancioneiro. Cultura Material. Vestir. Arquitetura. Joalheria. 
¡INTELIJENCIA, dame

el nombre exacto de las cosas!

... Que mi palabra sea

la cosa misma,

creada por mi alma nuevamente [...]

¡Intelijencia, dame

el nombre exacto, y tuyo,

y suyo, y mío, de las cosas!

(Juan Ramón Jiménez)²
2. Jiménez (1982, p.61-62)

3. Cancionero (1993, p 4-5). A no ser que se note lo contario, las citas de los poemas cancioneriles se hacen por la transcripción de Dutton (1990-1991), de donde se indica también el número de identificación de los poemas. Las citas del Cancionero de Juan Alfonso de Baena se dan por la edición de Dutton y González Cuenca (Cancionero, op. cit., 1993).

4. Ibid., p. 5.

5. Ibid., p. 5.

Citando la autoridad de Aristóteles, Juan Alfonso de Baena afirma en el Prólogo a su Cancionero "que por quanto todo omne de su propia naturaleza desea saber todas las cosas, que por esta razón quiere e ama e guarda más el omne los ojos que otra ninguna parte de su cuerpo, porque por sola vista se conosçen e se saben mejor e más aína todas las cosas que por otro sentido alguno." ${ }^{3}$ De aquí pasa a formular una poética visual al trazar una lógica que vincula el interés por el saber y el aprecio a los ojos con el "amar e cobdiçiar" los grandes y nobles señores la lectura de libros de armas y caballerías asentada en una base clásica (romana). Por el obvio servicio al buen gobernante que tales lecturas prestan, Baena menciona como lugar común la comparación de telas y vestidos ("paños e vestiduras") con los "libros e otras escrituras," con las que comparten, además de la variedad, calidad y valía ("muchos," "nobles," "preçiosos"), características visuales ("diversos colores e tajos nuevos e non vistos") que proporcionan un placer que es a un tiempo sensorial e intelectual. ${ }^{4}$ Esta finalidad última de las escrituras, la de llegar al corazón y la voluntad a través de una variedad polícroma que atrae y deleita los sentidos, invita a la comparación en el Prólogo de la relación entre lo escrito y el lector con la de otro deleite sensorial, el placer gustativo de los "sabores e bivos apetitos" que experimentan los señores delante de la comida ("diversos e preçiosos manjares"). ${ }^{5}$ No es aquí la imagen del festín una reiteración adornada de las teorías de la ruminatio, del acto de lectura como masticación lenta del texto regurgitado, sino la del libro como placer sensorial al que el lector se abalanza en virtud de la variedad y lo sabroso de su alimento. No es, entonces, el rumiar el concepto expresado en el texto, sino el comer con los ojos.

El acto de lectura y el consiguiente interés por los textos dan paso en el Prólogo de Baena a los "juegos ... e plazeres e gasajados" de los grandes señores, que van desde justas y torneos, toros, esgrima, juegos de lanzas, naipes, 
6. Ibid., p. 6.

7. Ibid., p. 7.

8. Weiss (1999).

9. Cancionero, op. cit., p. 659 , v. 6 .

10. Ibid., v. 13-16 ajedrez y dados, hasta, de manera extensa, la caza de leones, osos, ciervos y otros animales montaraces ("leones e osos e puercos e çiervos ... e vestiglos bravos e muy espantables"). ${ }^{6}$ El impacto físico y sensorial de estas actividades se presenta dentro de un continuum del que forma parte la lectura, el contacto con los textos, acto que no solo ilumina el entendimiento, reforma la memoria, alegra el corazón y consuela el alma, sino que por virtud del mismo "reposan todos los otros sentidos. "7 La poesía aparece en último lugar en el crescendo de placer y, prosiguiendo con la imagen de la delicia sensorial, con su dulzura engolosina a unos y a otros, a "oponientes" y "respondientes," de modo que el poeta debe saber dispensar la justa medida de miel, azúcar y sal en textos y ánimos.

Es importante destacar que la relación entre poesía y placer estético y sensorial no están, en el caso de Baena, absolutamente subsumidas a una teoría aristotélica del arte poética ni a una teoría horaciana de lo útil y lo dulce. Baena deja muy claro que el disfrute de la poesía se encuentra enmarcado dentro de otras actividades físicas contextualizables en los ámbitos en los que se mueve el autor y que son igualmente deleitables desde el punto de vista de los sentidos. De igual relevancia son las menciones a la cultura material en la que se desarrollan estas actividades de provecho y esparcimiento. Vestidos, armas, animales, alimentos aparecen en estrecha relación con la poesía en contextos muy concretos (caza, banquetes, conversaciones palaciegas). Baena pone de manifiesto que el prestigio de la poesía en estos entornos viene afianzado por el estatus social y el poder político de los ávidos lectores y, en último término, el del poeta. De este modo, la poesía entra en el mundo material no solo en virtud de las capacidades perceptivas de aquellos que poseen sensibilidades sublimes, sino también porque inscribe el entorno tangible en el que se mueve. El mismo Baena ilustra en su propia poesía esta relación entre poesía y materia, relación que ya señaló para Juan del Encina Julian Weiss. ${ }^{8}$ La radicación material y física de la poesía empieza por el cuerpo mismo del poeta, cuyas calidades dependen de su alimentación, las propiedades de la tierra en la que nació y del vestido que lo sitúa dentro de una esfera socioprofesional.

La constitución física del poeta y de la poesía como su producto pueden verse en poemas como "Johan Garçia, muy aína" (ID 1515), donde Baena transforma el azúcar poético en amargo acíbar ("xarope muy azedo") que administra a Juan García de Vinuesa, quien no había sabido o no había osado responderle a un poema anterior. 9 Pero el "manjar" poético que Baena envía a García de Vinuesa puede no ser grato al paladar de este poeta, por lo que Baena le sugiere alimentos más apropiados y que incluyen la sardina de Laredo, los rábanos de Olmedo, la gallina de Arjona. ${ }^{10}$ Las propiedades de la tierra se manifiestan en las 
bondades de sus frutos, entre los que se cuentan los alimentos enumerados, así como las calidades de las personas. Por esta razón, Baena niega la habilidad literaria de García de Vinuesa alegando como motivo su lugar de origen, Vinuesa de Melgar. "Al ser incapaz García de Vinuesa de manejar el arte poética, ejerciendo en su lugar un "arte tan mesquina," 12 Baena le propone actividades aldeanas más en consonancia con sus habilidades: hacer natas o coger bellotas. ${ }^{13}$ Son persistentes en la época posterior las referencias a la asociación de la bondad de la tierra cordobesa con las dotes personales de sus hijos, en particular la de la habilidad poética, como puede verse por ejemplo en la referencia a la elocuente Lozana andaluza, de quien dice Delicado que "Es parienta del Ropero [Antón de Montoro], conterránea de Séneca, Lucano, Marcial y Avicena. La tierra lo lleva, está in agibílibus, no hay su par [...]." 14 Por esta razón, no debe sorprender que Baena arremeta contra Diego de Estúñiga arguyendo que tal "simple escolar" obviamente aprendió su arte en tierras madrileñas o alicantinas, fustigándole con un "En Buitrago o en Villena / aprendiste el deitar" (ID 1553). ${ }^{15}$ En "Si vos fallastes la vena" (ID 1552), Diego de Estúniga había atacado a Baena en tales términos, achacando a la tierra natal rica en las berenjenas alusorias al judaísmo el estilo errado de su contrincante. ${ }^{16}$ En su respuesta Baena cambia las referencias a la comida por otras relativas a la ropa que significan el lugar que en el hacer textual y en el saber ocupa cada uno. La "rica trena" y el "lindo capellar," seguramente de seda, de Baena lo marcan en su respuesta como superior intelectual y socioprofesional del "simple escolar" que es Estúniiga, quien como tal solo es digno de cubrirse con simple lana: "Bien meresçe rica trena / el mi lindo capellar / e meresçe gran collar / quien vuestra lana carmena," 17 siendo muy posible que recaiga en Baena el esperado premio del gran collar.

Las constantes referencias a la simbología de la indumentaria en relación al saber, el "lindo capellar" en la poesía anterior o los "tapetes velludos" a los que se refiere Rodrigo de Harana en otra poesía (ID 1558), ${ }^{18}$ acompañan en muchos casos a las referencias a objetos relacionados con el mundo caballeresco no solo como símbolo o marca indumentaria sino como acompañamiento material a las contiendas poéticas. En "A vos, nobleçido, discreto, prudente" Baena "reqüesta" o desafía a un grupo de poetas dentro del que se encuentran Juan García de Soria y Rodrigo de Harana. La recuesta se hace por medio de un pavés o escudo alargado que porta un hidalgo cuyo nombre no especifica y que deberá recoger la respuesta de los contrincantes ("por ende, embío mi rico pavés / con este fidalgo a quien respondades," ID 1554). ${ }^{19}$ Asimismo, en la composición de carácter alegórico "Vi estar fermosa vista," Pero González de Uceda relata cómo tres contrincantes llevaron al juez una "razón" escrita en un pavés: "e levavan en un pavés / escripta atal razón:
11. Ibid., v. 22-24.

12. Ibid., p. 660 , v. 53

13. Ibid., p. 659 , v. $26-29$.

14. Delicado (1994, p. 348).

15. Cancionero, op. cit. (p. 690, v. 46-47).

16. Ibid. (p. 687-688).

17. Ibid. (p. 689-691, v. 2831). Sobre los capellares, véase Bernis (1979, p. 6869).

18. Cancionero, op. cit. (p. 694, v. 1).

19. Ibid. (p. 691, v. 27-28). 
20. Ibid. (p. 616, v. 13-16).

21. Sobre estos rollos, véase Gómez-Bravo (2013, p. 96100).

22. Yarza Luaces (1989).

23. Petrucci (1993, p. 7793).

24. Bouza Álvarez (2001, 2003), Castillo Gómez (2006). Véase también Casanovas et al. (2002), así como el clásico estudio de Simón Díaz (1995) para el Siglo de Oro. Para la importancia que tienen las consideraciones sobre el impacto del alfabetismo en la lectura y recepción de la poesía de cancionero, véase Gómez-Bravo (1999a, 1999b).

25. Cf. Edwards (1997).
/ 'Señor, oíd la entençión / de cada uno quál es" (IDO 11 1).20 En el primer caso el largo poema va acompañado del pavés, que quizá servía de soporte para su exposición pública, siguiendo la longitud del pavés a modo de rollo de forma similar a como se exponían los rollos litúrgicos. ${ }^{21}$ En el segundo caso, la "razón" se reduce a un breve poema de dos versos inscritos en el pavés mismo refiriéndose a los colores que lo portan, "prieto, verde, colorado," y a la simbología asociada con cada uno y que el poema desglosa. Este último caso sigue la práctica de la época evidenciada en artefactos del siglo XV conservados en otras partes de Europa, como es el caso de los paveses con inscripciones y pinturas alusivas originarios de lugares tales como Bohemia y Sajonia conservados hoy en museos como el Metropolitan Museum of Art.

La práctica poética que de forma tan gráfica propone Baena está lejos de responder a una conceptualización del texto como un ente que existe de modo independiente y que genera significado de una forma autorreferencial. Al contrario, el poema está en relación estrecha con el medio en el que se escribe y con un autor de carne y hueso radicado en una tierra específica, ataviado con los signos indumentarios de su particular nivel socioprofesional y cuyo quehacer poético viene alimentado literalmente por los frutos de su tierra y su entorno. De este modo, el poema textualiza la situación material constituyéndose en intermediario y creando una fecunda red de referencias entre el cancionero como libro y el entorno tangible en el que existe la poesía. Este proceso eleva lo material dotándolo de significado y, al hacerlo, lo sublima. Desde esta perspectiva el poema no puede considerarse una entidad exclusivamente retórica cuyo poder referencial es principalmente intertextual. Por el contrario, el poema, tal y como aquí se presenta, aparece inserto en la vida diaria dotando a los objetos de sentido e incorporándolos en un hilo narrativo que hace obvia la relación de la poesía con la cultura material. La conceptualización del poema como un texto móvil tanto más rico cuanto más varios son los soportes en los que habita (un texto multimedia en su sentido etimológico), conlleva la visualización del poema como entidad exenta del libro, aunque siempre en relación dinámica con el mismo. En esta línea, debe considerarse la propuesta de historiadores del arte como Yarza Luaces, quien ha llamado a un estudio integrado de la iconografía medieval y de fuentes textuales y culturales. ${ }^{22}$ Esta perspectiva se complementa con la de los estudiosos como Petrucci, quien ha hecho hincapié en el incremento del alfabetismo a lo largo del siglo $\mathrm{XV},{ }^{23}$ así como su impacto en los particulares usos públicos de la escritura y en la creación de una cultura gráfica, fenómeno que ha ocupado también a notables estudiosos de la literatura áurea como son Bouza Álvarez y Castillo Gómez. ${ }^{24}$ Por otro lado, se ha subrayado asimismo el posible uso aplicado del texto inscrito, que unido al objeto poseería un poder talismánico. ${ }^{25}$ Siguiendo esta línea debe considerarse la circulación de la poesía de cancionero fuera del libro, así 
como el valor del verso al grabarse en diferentes soportes materiales, creando estrechos vínculos entre papel y objeto, en algunos casos sin solución de continuidad.

Sin abandonar la debida consideración de las implicaciones que para la lectura tiene el fenómeno de inscripción multimedia de la poesía de cancionero, el presente trabajo se enfoca en los actos materiales de escritura y en lo que suponen para la constitución de la autoría. A estas se añaden otras, como son la consideración de las razones que motivan la decisión por parte del autor o la autora del tipo de soporte en el que se inscribe el poema, así como la del significado de este soporte, cuya importancia viene probada en gran número de poemas cancioneriles.

La condición palpable del poema inscrito en papel, piedra, barro, metal o tejido se foria con la ayuda de instrumentos de escritura que aparecen de continuo mencionados en la poesía de cancionero. Por ejemplo, Baena, se refiere con asiduidad a su "rica escribanía" y a las "cartas," "envoltorios" y papel con que se ayuda en su quehacer poético. Estos instrumentos llaman la atención hacia las cualidades materiales del poema mismo, que aparece unido a objetos que lo acompañan en forma de soporte material o como componentes activos del signo poético. ${ }^{26}$ Las cualidades materiales del poema comprenden las de sus soportes, como evidencian las referencias tanto textuales como pictóricas. Es bien conocida la representación pictórica del papel como soporte en referencia tanto a la práctica de colgar papeles sueltos en paredes o acompañando objetos, cuanto a imágenes pictóricas de páginas escritas. ${ }^{27}$ Un caso altamente ilustrativo es el del Retablo de los ángeles que Santillana mandó pintar a Jorge Inglés. En el codicilo a su testamento, Santillana dispone que se ponga el Retablo de los ángeles en el altar de la capilla mayor que manda hacer en la iglesia del Hospital de San Salvador de Buitrago. En este retablo aparecen pintados doce ángeles, cada uno de los cuales sostiene un papel manuscrito con una de las trece estrofas del poema de Santillana "Gózate, gozosa Madre." La última estrofa, copiada en el decimotercer papel pintado en el retablo, aparece al lado del conocido retrato de Santillana y contiene el único verbo en tercera persona. En esta estrofa el "Gózate" anafórico del resto del poema se torna en un "que goze" que apunta sin ambigüedades al poeta, retratado en posición orante al lado del papel. De este modo, la estrategia de la representación pictórica apoya la reformulación de un poema laudatorio en un poema de petición y, por tanto, en una oración personal. ${ }^{28} \mathrm{El}$ poema, como documento plasmado de forma plástica para su exposición pública, sostenido por ángeles dentro de una iglesia, hace permanente esta oración.

Los vínculos entre poesía y mundo material aparecen de modo patente en la poesía de Juan Álvarez Gato, donde un cuidado sistema de rúbricas muestra la
26. Sobre los diferentes aspectos relativos a las referencias a los materiales de escritura en poesía de cancionero, incluyendo los numerosos testimonios de Baena, véase Gómez-Bravo (2013, op. cit.).

27. Ibid.

28. Sobre este Retablo y la poesía de Santillana, son fundamentales los trabajos de Pérez Priego (2013, 2014, 2015). Sobre los detalles materiales de la elaboración del retablo, puede consultarse Silva Maroto (2012). 
29. Diversos aspectos relativos a la organización del libro de Álvarez Gato en Gómez-Bravo (2011).

30. En Dutton, op. cit.

31. Por ejemplo: "A Fernando, platero, para faser las hojas de plata, que se pusieron en vn paño de carmesy, de sobre vn albarda de camino, dos marços e vna onça e vna ochava de plata, e para hacer los rrotulos de las angarillas cinco marcos e vna onça e quatro ochavas, que son syete marcos e dos onças e çinco ochavas, que costo a 2.100 el marco, e por la echura de los rotulos 1.000 mrs., que son 16.389 mrs. Vna vara e seysma de terçiopelo carmesy, en que se bordaron honse varas de letras moriscas de hilo de oro, para guarniçion de vn tauardo, que costo a $2.700 \mathrm{mrs}$., que son $3.150 \mathrm{mrs}$. Treynta e dos onças de oro e de plata hila$\mathrm{da}$, que costo a $420 \mathrm{mrs}$. la onça, que monta 13.440 mrs., lo qual se gasto en las dichas honse varas de letras çinco onças e media e en los rotulos que se bordaron sobre el paño de carmesy çinco onças e media, e en la bordadura de vn sayo morisco 21 onças, con que se cumplen las dichas 32 onças. A Fernando de Couarruvias, bordador, por 45 jornales que puso en la dicha obra del sayo morisco, e por otros veynte que puso en el dicho paño, e por otros 22 jornales que puso en las honse varas de letras, que son 87 , a dos reales por cada jornal, que son 174 reales, que monta 5.394 mrs., e por la seda e grana de puntar 405 mrs., que son todos $5.799 \mathrm{mrs}$. (Torre y del Cerro; Alsina 1955, p. 166). impronta del arraigo material de su poesía. El libro de Álvarez Gato está estructurado en forma de progresión espiritual sostenida por una poética subyacente que está radicada en sus condiciones materiales y sociales. ${ }^{29}$ Álvarez Gato contextualiza su poesía dentro de la situación material de la que emerge, arraigando una poesía voluntariamente conceptual en lo específico del aquí y el ahora. Esta contextualización aparece no solo en los poemas que se presentan claramente ligados a unas situaciones materiales o sociales específicas que vienen detalladas por las rúbricas, sino también, de manera más tangible, mediante un vínculo explícito entre poema y objeto. Este es el caso de las dos series de poemas breves, algunos denominados letras, destinados a inscribirse en diversos objetos de los que la rúbrica da razón. La primera serie se refiere a objetos de carácter cortesano y caballeresco, mientras que la segunda serie se refiere a objetos religiosos y conlleva un contenido espiritual acorde con la segunda parte del libro. Debe quedar claro que estos poemas no aparecen caracterizados como invenciones, sino agrupados de forma genérica de acuerdo a criterios formales por razón de su brevedad y de su relación con los objetos específicos en los que están escritos. Su inscripción estaba efectuada mediante bordado, grabado, pintura o el método que mejor se adaptase a la naturaleza de cada soporte. El poema podía también copiarse en un papel que, unido al objeto, facilitaba un proceso de transferencia de objeto a documento. De este modo el poema conllevaba una alta referencialidad material al conservar el texto la traza del objeto aludido. La destrucción material de artefactos medievales a lo largo de los siglos puede crear la percepción de que estos textos y su contextualización son solo un juego retórico que no localiza el poema más que en la página en la que se encuentra copiado. Esta percepción viene refutada por la conservación de diversos artefactos que aparecen en inventarios de la época o también en forma de vestigios tangibles conservados en museos y otros archivos.

La primera parte del libro de Álvarez Gato contiene una corta serie formada por poemas inscritos en un collar de oro, en su capa acompañando una imagen bordada y en un almete: ID3078 ("sacando un canto dorgano bordado en vna capa"), ID3079 ("otra letra a vna vista de vn almete bordada"), ID3080 ("Sacando vna villa por çimera"), ID308 1 ("cançion que hazie a lo en quel estaua"), ID3082 ("esta letra saco en vn collar de oro que hizo de vnas limas Sordas"). ${ }^{30}$ Aunque estos poemas aparecen en serie armónica organizados de forma genérica, las rúbricas dan fe de la dependencia material y situacional del poema. Pueden atestiguarse las prácticas suntuarias textualizadas en la obra de Álvarez Gato examinando fuentes documentales como la de los pagos de "letras" y "rótulos" para vestidos detallados en el libro de cuentas de Gonzalo de Baeza. ${ }^{31}$ El uso combinado de objetos personales y versos, junto con el frecuentísimo uso ornamental y poético de las iniciales, puede asimismo 
verse en el ejemplo concreto de un collar similar al de Álvarez Gato mencionado en las Batallas e Quinquagenas de Fernández de Oviedo, donde se describe uno que adorna a Johan Coloma: "Trae [tachado: como lo veys] vna muy hermosa e gruesa cadena de oro [tachado: de más de veinte marcos de oro e muy rricamente labrada e esmaltada] y por ella de rrelieve muchos caracoles en tanta perfiçión e arte que era cosa mucho de ver e contemplar el primor del artífiçe que la hizo. Pero porque mejor os quadren sus versos ya os he dicho en otras partes que los que invinçionan o toman devisas procuran de las tomar que conforme el nombre de la invençión con la primera letra del nombre de la señora, o del sobrenombre, si es posible. Y así el secretario ... miró en este primor, pues que su muger tenía por sobrenombre Caluillo, y a este propósito son los caracoles de su hermosa e gran cadena." 32 Este collar y el de Álvarez Gato presentan claros ejemplos de las prácticas textuales en ámbitos extracodicológicos como es en este caso el de la orfebrería. En relación con el almete glosado por el poema de Álvarez Gato, puede mencionarse el almete contemporáneo del poeta que se encuentra custodiado dentro de la colección de objetos artísticos de la Real Academia de la Historia. ${ }^{33}$ El almete lleva la siguiente inscripción grabada en letras góticas: "Dicen mi bien e tormento las letras de aqveste asiento." La " $\mathrm{N}$ " de la palabra "asiento" está situada en la base o asiento de la cimera del almete que, como notaba Márquez Villanueva, podía estar constituida por penas. ${ }^{34}$ No puede, si embargo, ser coincidencia que la letra elegida para aparecer en posición central del asiento mismo sea la "N" de No, letra que podía también ser la inicial de la dama, explicándose entonces por qué esta letra es fuente tanto de bien como de tormento. Al mismo tiempo, la palabra "asiento" [de 'asentir'] indica un "sí" que asiente en contraste a la N del "no." La referencia a la inicial estaría en línea con la tradición poética de glosas de las letras del nombre de la persona amada, así como también de la que podría considerarse obsesión por las letras iniciales que documentan ampliamente los inventarios de joyas y objetos personales de la época. La reina Isabel poseía, por ejemplo, un volante adornado con 18 efes y 6 perillas de oro, entre otras muchas joyas compuestas de la misma letra $f$, alusiva a Fernando; joyas que la reina llevaba como esposa fiel y que ayudaban a comunicar la solidez de su yugo matrimonial y real. ${ }^{35}$ Es bien sabido que las iniciales de Isabel y Fernando, acompañadas de sus emblemas y del lema "tanto monta," también adornan en profusión estructuras arquitectónicas como es el interior del Monasterio de San Juan de los Reyes de Toledo, así como el artesonado del techo del claustro alto del mismo Monasterio, en cuyo centro aparece el león rampante, desde donde salen como rayos de sol el resto de los componentes. ${ }^{36}$ Asimismo aparecen las iniciales de Isabel y Fernando en objetos personales descritos en los inventarios de bienes, como es el caso de la manilla de oro esmaltada en negro con "vna efe esmaltada del mesmo esmalte." 37 Igualmente pueden observarse en obras de arte,
32. Fernández de Oviedo (1989, p. 467-468).

33. Foto y descripción en Tesoros... (2001, p. 253254).

34. Márquez Villanueva (1960, p. 214n).

35. Torre y del Cerro; Alsina (1974, p. 70). Entre otros ejemplos, pueden citarse: "Vna axorca que tiene ocho pieças encharneladas y esmaltadas de rrosicler e blanco e negro, que se çierra con una $F$ hecha como candado e dos cabos de agujetas;" las "Seys efes de oro chequitas, lisas, que estan en vn papelejo;" dos brazaletes en oro y esmaltes "abiertos de vnas efes;" así como la manilla en oro y diamantes con una $f$ esmaltada en negro. Ibid. (p. 24, $27,64,66$ respectivamente).

36. Yarza Luaces (2005, p. 15-24).

37. Ibid. (p. 66). 
38. La descripción de este manuscrito y su funda aparece en inventarios tales como el del Archivo General de Simancas: "Vn libro grande escripto en pergamino, de mano, que son Las syete Partidas con sus fechos, de plata dorada, que van asydos en vnos texillos de plata tirada, que tiene vna $F$ en la vna parte e en la otra vna Y de la dicha plata coronadas, con la cubierta de açetuni morado. Apreçiose plata e libro, como esta en 5.251 mrs. Paresçio por el libro de Juan Velazques como se dio al Rey don Hernando nuestro Señor, que santa gloria aya" (Contaduría Mayor, 1a época, leg. 81, pl. 44), publicado en Torre y del Cerro; Alsina (Ibid., p. 96).

39. Fernández de Oviedo (2008, p. 430).

40. Marcuello (1987, fol. 22r, 61v, 62v)

41. Marcuello (op. cit., p. 91). como es por ejemplo la encuadernación de las Siete Partidas conservada en la Biblioteca Nacional de Madrid (Vitr. 4-6), cuyos ocho broches aparecen además esmaltados con el yugo (parte anterior de la encuadernación donde va la $Y$ de Isabel) y flechas (posterior, acompañando la F de Fernando). El manuscrito, del siglo XV, había pertenecido al primer Duque de Arévalo, don Álvaro de Zúñiga, cuyo escudo decora el primer folio y la encuadernación. Puede verse en la composición de este códice un macro-signo bibliopolíitco, al envolverse un libro que había pertenecido a la nobleza en una funda adornada con los símbolos gráficos de la monarquía católica, una monarquía que no elimina los blasones nobiliarios, pero sí los engloba y supedita a si misma. ${ }^{38}$ Estas son referencias gráficas que unen libro y obras arquitectónicas y ornamentales con unos mismos fines político-estéticos. En relación con el énfasis en las iniciales, tanto por parte de Isabel y Fernando como de la sociedad cortesana más amplia, debe citarse otro testimonio de Gonzalo Fernández de Oviedo, quien destaca los usos políitico-sociales de letras y divisas en varios lugares de sus Batallas y Quinquagenas: "muy acostumbrada cosa es en nuestra España, entre caballeros e señores, procurar que la invençión comiençe su nombre en la primera letra del nombre de la señora por quien se invençiona, demás del atributo o sinificaçión de lo que quieren magnifestar o publicar con esas devisas. E guardando esta orden, el Cathólico Rey don Fernando trahía un yugo, porque la primera letra es Y por Ysabel; y la Reyna Cathólica trahía por divisa las frechas, que la primera letra es F, por Fernando." 39 Las iniciales de los monarcas aparecen pintadas y glosadas en el Cancionero de Pedro Marcuello, que porta las iniciales de Isabel y Fernando en varios de sus folios ${ }^{40}$ y explica claramente la semántica plurivalente de estas iniciales:

\footnotetext{
Del fenojo en Aragón

la effe es letra primera

y en Castilla, en conclusión,

nombrándolo por razón,

es la y más delantera

Estos son sinificados

de vos, altos Reyes dos;

quan bien son considerados,

allamos que soys juntados

para servicio de Dios ${ }^{41}$
} 
En este cancionero, el yugo y las flechas funcionan también como iniciales ideográficas o parlantes, al igual que lo hace el hinojo, ${ }^{42}$ como explican los versos:

\author{
Deste yelmo: la cimera \\ trahe dos sinifficados \\ destos Reyes prosperados. \\ Llámala Castilla ynojo \\ ques su letra de Ysabel \\ y de lhesús Hemanuel. \\ Llámala Aragón ffenojo, \\ ques su letra de Fernando \\ y de ffe las dos de un vando. ${ }^{43}$
}

Son de destacar los paralelismos en los usos de una práctica gráfica que sitúa estas letras fe y en un lugar central y que supedita a ellas el resto del universo simbólico. Sin solución de continuidad con las prácticas gráficas patentes en obras de arquitectura, joyería, orfebrería, bordado están la codicología, paleografía y el arte pictórico. Las relaciones gráficas entre objetos tales como joyas, prendas de vestir, piezas de armadura o cubiertas de libro y el texto manuscrito invitan a la consideración de los aspectos materiales de la razón gráfica.

Con tal fin debe considerarse la serie de invenciones cortesanas del cancionero de Álvarez Gato ya comentada, así como su equivalente, la larga serie de trece poemas de carácter religioso-moral de la segunda parte del cancionero. Estos trece poemas estaban también inscritos en soportes varios, tales como tejidos, armadura y piedra, apareciendo en espejos, tumbas, pendones, o paredes, según nos explican las rúbricas. Uno de los poemas se encontraba escrito, según la rúbrica, alrededor de un espejo, mientras que otro se dirige al espejo mismo, al que el poema transforma en símbolo mariano. Un tercero estaba escrito en un pendón que ondeó en la guerra contra los musulmanes. ${ }^{44}$ Las armaduras y objetos de uso bélico eran soportes usuales de textos e imágenes que se unían en el objeto para formar un significado alusivo. Los artefactos de esta naturaleza que se conservan demuestran unas relaciones recíprocas entre los varios soportes textuales, basadas no solo en la mera presencia de letras, sino también en la naturaleza gráfica de las prácticas textuales. Sendos poemas "a nuestro Señor" y "a la Cruz"
42. Marcuello (op. cit., fols $7 \mathrm{v}, 39 \mathrm{v}$ y fols. $22 \mathrm{r}, 36 \mathrm{v})$.

43. Marcuello (op. cit., p. 61). Sobre las miniaturas del Cancionero de Marcuello, debe consultarse Bernis (1952). Sobre el significado político de las miniaturas de este cancionero, véase el estudio de Weissberger (2005).

44. ID3152 ("esto se puso en vn pendon de la guerra de los moros"), ID3154 ("A nuestra señora al Rededor dun espejo"), ID3155 ("otra letra al espejo"), ID3161 ("trae por deuisa vnos manojos de cabos de texillos mucho tienpo ha dize la letra"), ID3162 ("dize al Rededor duna tumba"), ID3163 ("dize en vn paño questa ençima la tunba en questa vna cruz de gerusalen hablando con dios"). Al encontrarse dentro de la misma serie, hay que interpretar las siguientes rúbricas también como indicadoras de una idéntica situación material: ID3156: "Otra letra a nuestro Señor," ID3157: "otra a la Cruz," ID3158: "dize vn escudo ado estan ynsinias de la pasión,” ID3159: "dize vn contenplatiuo questa de Rodillas al pie del escudo," ID3160: "Juan aluarez / habla con su alma." Dutton, (op. cit.). 
45. Aparece en el fol. 66v $\left(n^{\circ}\right.$ 97) y va encabezado por la rúbrica: "trae por deuisa vnos manojos de cabos de texillos mucho tienpo ha dize la letra." El breve poema reza: "Procuremos buenos fines / que las vidas mas loadas / por los cabos son juzgadas." Una versión de este poema, con la rúbrica que lo presenta como epitafio de Álvarez Gato, aparece copiada en el fol. 11r (ID3090, $\mathrm{n}^{\circ} 23^{\mathrm{a}}$ ) por otra mano: "Juan Aluarez Gato Fué Noble y gran Cauallero natural de la villa de Madrid. Sus pasados que son antiguissimos en ella tienen sus entierros en la parroquia de S. Saluador. Y sus casas cerca de la misma parroquia. Deste cauallero y de sus escritos hace mencion en la historia de Madrid el Maestro y Coronista Gil Gonçalez Dauila. Este cauallero tenia en su sepultura los versos siguientes: Procuremos buenos fines / que los medios acertados / por los cabos son juçgados." Dutton (op. cit.).

46. Dutton (op. cit.).

47. Dutton (op. cit., vol. 2, p. 19 , v. 1-5).

48. Puede encontrarse una reproducción del dibujo que aparece en el manuscrito en Dutton (op. cit., vol. 2, p. 19). refieren a imágenes encontradas en una iglesia o en una residencia, aunque en este caso la rúbrica no da la información completa sobre el lugar en cuestión. Esta serie, seguida por ID3 158 (escrito en un escudo con las arma christi) y por ID3 160, en el que el poeta habla con su alma, se caracteriza por un énfasis en el tema de la Pasión. Algunos de estos poemas sugieren una representación gráfica de los objetos descritos, junto a un texto acompañante, en el soporte primario. Uno de los poemas de esta serie (ID3 161) acompañó una divisa de Álvarez Gato y también se escribió en la tumba del poeta, según nota del manuscrito de la Real Academia de la Historia. ${ }^{45}$ Los últimos dos poemas de la serie se pusieron en una tumba (ID3 162) y el segundo en un paño que cubría la tumba (ID3163), al igual que lo fue un poema de Álvarez Gato que se incluye en MP2, pero no en MH2: ID2071 ("Letra que esta en la sepultura del Conde don Perançures en la yglessia Mayor de Valladolid"). La naturaleza física del poema como artefacto facilitaba su exhibición pública, como da fe el poema que aparece en el eje de la división central del libro de Álvarez Gato y que lleva la rúbrica: "Al pie dun cruçifiçio questa en Medina sobre vna pared hecha de huesos de defuntos puso esta copla para que veamos claramente como somos todos duna masa y que essos deven ser auidos por mejores que tovieren mas virtudes pues que linaje dispusicion y fama y Riquezas todo pereçe" (ID 1 045). ${ }^{46} \mathrm{El}$ poema se dirige al que observa la pared hecha de huesos de muertos para recordarle el poder igualitario de la muerte, que permite que los huesos de ricos y pobres se apilen en confuso desorden en lo que es claramente un desconcierto del orden social. Esta pared es similar a otras existentes en Europa, tales como la Eggenburg Charnel en Eggenburg, Austria, y las posteriores de Santa Maria della Concezione dei Cappuccini de Roma, y la Capela dos Ossos de Évora, en una de cuyas paredes también cuelga un poema alusivo invitando a una reflexión sobre la muerte. Cuando el poema se inscribe en soporte que difiere del que acoge el estímulo visual al que acompaña, o que le acompaña, el poema es un artefacto independiente pero inserto en una situación cuyo significado explica el papel poético. Es entonces cuando se acerca más al códice que a la poesía epigráfica, en lo que podría considerarse un estadio "pre-macrotexual" en el que no está completamente inserto en el libro archivo. En un segundo estadio, tal inserción conllevaría la sustitución de la imagen externa por una rúbrica que textualizaría lo extratextual. Es posible ver un ejemplo de tal estadio intermedio en el caso del poema: "Mira y veras tu traslado / si vien te quisieres ver / mira quan desfigurado / quan feo y dessemejado / a la fin te as de bolver" (ID0240, MN6d). ${ }^{47}$ Este poema podría leerse junto con el de Álvarez Gato, ya que también apela al lector a que contemple su suerte en la calavera y huesos que en este caso aparecen dibujados en tinta en el manuscrito, en el que la imagen dibujada en papel cumple la misma función que la rúbrica (que en este caso falta). ${ }^{48}$ Caso 
similar es el de la compilación de las obras de Gil Vicente, en la cual aparece un grabado con la calavera y huesos inserto entre las dos estrofas del poema "O gram juyzo esperando," que cierra el libro. La rúbrica ("Sepultura de Gil Vicente") lo presenta como epitafio de la tumba de Gil Vicente, con lo que el poema, como es de esperar, trata de la muerte y el reposo eterno, mientras que pide al "leitor" que lo mire y tome como espejo, en clara referencia al grabado. ${ }^{49}$ Rubricación pictórica aparece igualmente en BU 1, al final de la serie de las letras que acompañaban a sendas cimeras en las justas barcelonesas del 22 de abril de 1486. Trece de las dieciséis letras están encabezadas por una rúbrica explicativa que detalla las características visuales de cada cimera. La última letra (ID8 158) carece de tal explicación y en su lugar el copista parece haberla suplido con una ilustración propia. La letra "El speransa del subir / aze alegra mi biuir" aparece encabezada por un parco "Otra" pero con un dibujo lateral de un castillo bajo el que aparece una escala y sobre el que está dibujada una A decorada a modo de artilugio guerrero, probablemente un ariete o aries, y posiblemente alusivo a un nombre femenino con inicial en A, como parece indicar el ariete y el "alegra" del verso, cuya fortaleza espera escalar el poeta. ${ }^{50} \mathrm{El}$ objeto se une así al poema en su soporte en papel como rubricación visual, en forma de imagen. De este modo la poética responde o se une a su contexto material y lo inscribe.

La consideración de los objetos en los que aparecen escritos versos y otra diversidad de textos invita a considerar el carácter material de la elaboración del texto y su medio, así como los procesos que marcan las transferencias entre los varios soportes gráficos. Una indicación de los posibles procesos que marcan el paso de un soporte a otro es la que aparece aludida en obras como el Don Florindo de Fernando Basurto, donde se da cuenta del acto de registro de letras, divisas y soportes ("arreos y atavíos") por parte de los jueces, acto que textualiza los soportes gráficos. ${ }^{51}$ La a veces difícil legibilidad de las letras pintadas, bordadas o grabadas en espacios públicos y en diferentes soportes aparece también testimoniada en la misma obra a través de los esfuerzos por parte de los asistentes a justas y torneos por averiguar el contenido de los versos inscritos en diversos artículos indumentarios, así como el significado de estos y de su acompañamiento visual ("la devisa y letra"). ${ }^{52}$ Debe tenerse en cuenta en este sentido el testimonio de Garcia de Resende, quien considera algo impacientemente los trabajos que el paso de un soporte a otro implica para el cronista, ocupado en compilar en papel los textos publicados en tan variados soportes. En la relación de las magníficas justas celebradas por el rey João II que aparece en su Chronica de el-rei D. João II, Garcia de Resende considera el tránsito de los textos inscritos en armas y vestiduras al papel, junto con las implicaciones del mismo para la
49. Vicente (1983, p. 667).

50. Dutton, (op. cit., vol. 1, p. 41).

51. Fol. 49v. Texto en Río Nogueras (1994, p. 317).

52. Fol. 51r. Río Nogueras (op. cit., p. 318). 
53. "Y la justa fue muy bien justada y diéranse en ella muchos y grandes encuentros, sin haber peligro alguno. Y la cimera del rey y de sus mantenedores y sus letras escriví aquí y así[mismo] las de los aventureros de las que me acordé. Y que a algunos esto parezca bajo, otros habrá que que se alegrarán de oirlo, que quien escribe no puede contentar a todos, y no hará poco si de pocos fuere tachado, que todos quieren enmendar y muy pocos escribir. $\mathrm{Y}$ para evitar esto no debía haber otra pena más que ponerles a los glosadores papel y tinta en las manos y hacerlos escribir a la fuerza; y sería muy buen freno para los desbocados que sin saber lo que dicen, glosan lo que no entienden" [traducción mía]. Resende (1994, p. 342).

54. Casas Rigall (2013). Véase también Casas Rigall (2008).

55. Barroca (2000).

56. Ostos Salcedo (2010). valoración de la labor del escritor. Afirma Garcia de Resende que "E a justa foy muyto bem justada, e deram-se nella muytos e grandes encontros, sem aver perigo algum. E a cimeyra d'el-rey e dos seus mantedores e suas letras escreverey aqui e assi das dos aventureyros que me lembrarem. E que a alguns ysto pareça sobejo outros avera que folgaram de o ouvir, que quem escreve nam pode contentar a todos, e nam faraa pouco se de poucos for tachado, que todos querem enmendar e muy poucos escrever. E pera se ysto evitar nam devia d'aver outra pena senam aos grosadores meter-the papel e tinta nas mãos e fazê-los per força escrever, e seria muito bom freo pera os desbocados, que sem saber o que dizem, grosam o que não entendem." 53 Lo que interesa destacar aquí es que, más allá de una simple práctica epigráfica y más allá del interés del uso de la escritura en espacios públicos en la creación de una cultura gráfica, estos textos ayudan a trazar una relación directa entre soporte escrito y una textualización de lo material que va desde el objeto a la representación gráfica del mismo para terminar en su textualización. La copia en papel de los versos y de su estímulo visual textualizado en forma de rúbrica o de otro tipo de breve narrativa o micronarrativa, en término usado por Casas Rigall, ${ }^{54}$ da al códice el carácter de memoria o registro. El acto hermenéutico que entrañan las pesquisas sobre la poesía y su acompañamiento visual, el soporte y el objeto patente o representado, -y la relación entre todos ellos- conlleva un acto de lectura contextual con fuertes implicaciones para la conceptualización de la autoría en sus aspectos materiales. El estudio de los artefactos utilizados invita a una colaboración interdisciplinar no solo de literatura y arte, sino también de epigrafía y diplomática. En este sentido son de interés aproximaciones como la de Barroca, ${ }^{55}$ quien ha estudiado los procesos generativos de la inscripción, desde el comandatario en las mandas en testamentos, hasta autoría, minuta y ordinatio, pasando por los varios aspectos materiales de su ejecución. Igualmente importantes son contribuciones como la de Ostos Salcedo, ${ }^{56}$ quien ha puesto de relieve las coincidencias gráficas entre los elementos organizadores del códice, como son rúbricas o tífulos corrientes, con los de la práctica epigráfica. Muchos de los versos inscritos en objetos o en lugares públicos o de uso en común se copiaban en compilaciones poéticas, pasando de armadura, vestido u objeto a papel y libro. Es de gran importancia considerar las implicaciones que el paso de un soporte al otro tienen para la labor escrituraria, ya que la consideración de la autoría debe en consecuencia ampliarse teniendo en cuenta la labor gráfica de menestrales tales como bordadores, orfebres, albañiles y grabadores.

De la importancia de la labor gráfica fuera del papel y del códice dan fe numerosos textos en prosa y verso donde se destaca la unión de versos con soportes 
tan diversos como son los objetos cotidianos en los que se encuentran labrados, bordados, pintados, grabados o delineados. De modo similar a lo observado en la poesía de Álvarez Gato y en las otras obras aquí estudiadas, aparecen inscripciones en verso en un palacio en Triste deleytaçión, ${ }^{57}$ en la tumba de Fiometa en el Grimalte y Gradisa de Juan de Flores, ${ }^{58}$ en telas o alrededor de objetos tales como espejos en Qüestión de amor, ${ }^{59}$ o en tumbas (en el paño que cubre la tumba de Violina en Qüestión de amor). ${ }^{60}$ Aparece también un vaso esmaltado con una copla y versos bordados en perlas en un brial y en un mantillo en Triste deleytaçión. ${ }^{61}$ En gran variedad de materiales tales como piedras, árboles y libros de memoria, - colgados por las paredes aparecen inscritos los poemas contenidos en la compilación de las poesías de Pedro Andrade de Caminha o en obras tales como el Tirant lo Blanc estudiado por Rafael Beltrán, o el Don Polindo y el Don Florindo de Fernando Basurto estudiados por Río Nogueras. ${ }^{62}$ En estas obras se hallan además poemas inscritos en toda suerte de prendas de vestir (ropas, sayos, mangas, gorras, ropetas), así como en armas, escudos, cubiertas, tiendas de mantenedores, palenques y paramentos. En un árbol aparece inscrito un mote en Siervo libre de $a_{m o r}{ }^{3}$ y en la brida del caballo lleva Santiago escrito su nombre en una de las miniaturas del Cancionero de Pedro Marcuello. ${ }^{64}$ Los usos de objetos con inscripciones vienen documentados en relaciones tales como la de las festividades celebradas con motivo de las bodas de Lucrecia Borgia, ${ }^{65}$ donde se ven invenciones y motes en latín en vasos y otros objetos. ${ }^{66}$ En las mismas fiestas se sacan para una colación, en palabras de la autora, "dies platos con diversas y muy lindas invenciones y motes, todos de muy galana fantasía; los cuatro eran dirigidos a su santidad; los otros a cada uno de los otros como era uno para la señora doña Lucrecia, otro para el señor don Alonso, otro para el señor Príncipe, otro para el Cardenal de Perusa, otro para el señor Cardenal, otro para mi [...]."67 Las invenciones son una mujer con un pomo en la mano que es el mundo, un niño, una mujer en forma de la Lucrecia clásica, un oso, un caballo de armas enviado por la diosa de las batallas, un hombre dormido y un unicornio. ${ }^{68}$

Los objetos de uso personal se constituyen con gran frecuencia en soporte textual y artístico, uniéndose en ellos poesía e imagen, contextualizadas ambas en la ropa, persona y situación en que se usan. En el Veneris tribunal de Ludovico Scrivá hay versos alusivos en diferentes prendas de vestir y objetos personales, incluyendo coleto, capa, gorra, jubón, camisa, ropeta, ${ }^{69}$ además de unos guantes, ${ }^{70}$ una medalla de oro, ${ }^{71}$ el pomo de una espada ${ }^{72}$ y la vaina de una espada. ${ }^{73} \mathrm{En}$ Siervo libre de amor aparece un manto con ballestas cercadas de letras, ${ }^{74}$ junto con cotas bordadas con la empresa de los tres bastidores y sus letras alusivas. ${ }^{75}$ Igualmente inscritas con versos están las prendas que viste Leriano en la continuación
57. Triste... (1982, p. 15).

58. Flores (1998, p. 134137).

59. Menéndez y Pelayo (1907, p. 47, 56 et passim).

60. Menéndez y Pelayo (op. cit., p. 48).

61. Triste... (op. cit., p. 16, 17).

62. Caminha (1989); Beltrán (2005); Río Nogueras (1994).

63. Rodríguez del Padrón (1976, p. 77).

64. Marcuello (op. cit., fol. 125v).

65. Uhagón y Guardamino (1916, p. 81-98).

66. Uhagón y Guardamino (Ibid., p. 92-94).

67. Uhagón y Guardamino (Ibid., p. 92).

68. Uhagón y Guardamino (Ibid., p. 64).

69. Scrivá (1983, p. 19-21).

70. Scrivá (Ibid., p. 20).

71. Scrivá (Ibid., p. 20, 22).

72. Scrivá (Ibid., p. 20, 22).

73. Scrivá (Ibid., p. 22).

74. Rodríguez del Padrón (op. cit., p. 86).

75. Rodríguez del Padrón (Ibid., p. 85). 
76. Whinnom (1979, p. 57).

77. Whinnom (Ibid., p. 5859).

78. Whinnom (Ibid., p. 58)

79. Whinnom (Ibid., p. 6163).

80. Whinnom (Ibid., p. 59).

81. Whinnom (Ibid., p. 4445).

82. San Pedro (1973, p. 111114).

83. San Pedro (Ibid., p. 112113)

84. San Pedro (Ibid., p. 174).

85. San Pedro (Ibid., p. 176).

86. Foto en Yarza Luaces (1992, p. 75).

87. Foto en Yarza Luaces (Ibid., p. 163).

88. Esta capilla fue mandada construir a finales del XV por don Gonzalo de Illescas, oidor de la Chancillería, y su mujer Marina de Estrada, según dice la larga inscripción que rodea las paredes de la capilla. Sobre este retablo y la capilla, véase Ara Gil (1977, p. 333-337). Sobre San Gregorio y San Pablo de Valladolid, es también fundamental Ara Gil (1999). Sobre San Gregorio debe asimismo consultarse Molina de la Torre (2013) y la bibliografía allí citada. de Cárcel de amor de Nicolás Núñez y que incluyen bonete, camisa, ${ }^{76}$ jubón, sayo, cinto, calzas, agujetas, capa, zapatos, guantes, ${ }^{77}$ además de un puñal y la vaina de una espada. ${ }^{78}$ Por su parte, Laureola lleva versos inscritos en prendas de su indumentaria como son cinta del pelo, camisa, brial, cinta de caderas, faldilla, tabardo, manto, guantes y alcorques. ${ }^{79}$ Las letras de los guantes, eles y aes, siguen la moda de las iniciales, acompañando a los versos que explican su clara referencia a Laureola: "Assí comiença y finece / el nombre que más merece." 80 Versos bordados en diferentes prendas de vestir aparecen asimismo en ropas de pajes en La coronación de la señora Gracisla. ${ }^{81}$ En el Tractado de amores de Arnalte y Lucenda aparecen poemas bordados en un manto en el contexto público de la celebración de momos en sala, ${ }^{82}$ donde Arnalte exhibe una cimera con un peso y una letra de tres versos. ${ }^{83} \mathrm{El}$ carácter público y la función retórico-social del mensaje bordado vienen explícitamente aludidos en el conocido comentario que Diego de San Pedro hace en su Sermón, donde advierte contra la práctica de los amadores de publicar su afán amoroso por medio de bordados alusivos ("bordar invenciones que lo publiquen"). ${ }^{84}$ Es también conocida la crítica que la pública exhibición de los sentimientos por vía tan personal originó en el mismo escritor, quien afirma en su Sermón: "Ved qué cosa tan errada es manifestar en la bordadura aun lo que en el pensamiento se deve guardar; y no menos, señores, os escusad de vestiros de sus colores, porque aquello no es otra cosa sino un espejo do se muestra que la servís." ${ }^{85}$ El poema "Por hazerme mas crueza" (ID6567, 11 CG) recomienda la inscripción de diversas partes del atuendo personal en preparación de una fiesta. El duque de Medina-Sidonia, autor del poema, se propone llevar bordados unos manojos verdes en la ropa junto con una letra compuesta de tres versos en los que afirma la pérdida de la esperanza que este color simboliza. El poeta continúa afirmando que en el jubón sacará bordadas unas lágrimas con otros tres versos alusivos al sufrimiento que le hace verterlas. Por último, en el sombrero sacará unas proverbiales penas que glosará con otros tres versos. Estas prácticas aparecen también documentadas en las artes pictóricas. Puede, por ejemplo, mencionarse la miniatura del folio 54v del Cancionero de Pedro Marcuello, en la que el borde del vestido de la reina está adornado con palabras, entre las que parece distinguirse 'coeli' y 'fides,' entre otras de difícil lectura. Igualmente aparecen letras bordadas en el vestido de la Virgen en el Tríptico de la Adoración de los Reyes Magos hoy en el Museo de la Colegiata de Covarrubias en Burgos, ${ }^{86}$ así como en el de San Andrés en el Tríptico de la Virgen de la Rosa hoy en el Museo de la Catedral de Salamanca, del pintor Fernando Gallego. ${ }^{87}$ Asimismo, muchas de las figuras representadas en el retablo de la capilla de San Juan Bautista de la iglesia de El Salvador de Valladolid tienen vestiduras bordeadas de cenefas de letras. ${ }^{88}$ También un manto ornado con letras viste la Virgen con el Niño de la iglesia parroquial de 
Villavicencio de los Caballeros. ${ }^{89}$ En consonancia con estas muestras de la pintura está la referencia a tales prácticas que existe también en los cancioneros, como es el caso del poema "Remoto a vida mundana" (ID0306) del Marqués de Santillana, donde la Virgen aparece con ropa bordada con proverbios de Salomón: "vestida de perfeçion, / de motes de Salamón / toda la ropa bordada." 90

Por ser de tal modo significativas y documentar los usos públicos de la combinación de texto y referente visual, las referencias literarias deben considerarse de la mano de los testimonios presentes en crónicas, inventarios, fuentes iconográficas y en los mismos objetos conservados, de los que dan rendida cuenta los inventarios de bienes. Como muestra pueden mencionarse la copa en la que se encontraban letras grabadas en esmalte y que pertenecía al rey Juan II, tal y como se describe en el inventario real, ${ }^{91}$ así como los numerosos anillos, espadas y otros artefactos con letras grabadas descritos en los inventarios reales. ${ }^{92}$ Una joya guardada en la antecámara del rey don Juan $I I$ y que había pertenecido a don Juan de Luna tenía una copla escrita en la bolsa: "Iten otro joyel que se dize del toque que es vna bolssa de oro esmaltada de blanco puesto en la boca della vn balax grande e en la dicha bolsa scripta vna copla e colgauan de los çerraderos della veynte e quatro puntas de toques. "93 En la Real Armería de Madrid se conserva la espada de Fernando láanteriormente de Isabele) (Inv. G 31 ) en cuyo pomo están grabados los siguientes versos, escritos a la redonda y altamente alusivos: "paz comigo nvnca veo / i sienpre gvera deseo." ${ }^{194}$ En el inventario del tesoro de Enrique IV publicado por Ladero Quesada y Cantera Montenegro se encuentran numerosos objetos inscritos con rótulos de letras, tales como: "6 jarros de plata nuevos, 4 del tiempo viejo; los bebederos y asientos dorados; 5 de ellos con unos rótulos por medio, dorados, con letras; pesaron 14 mar., 2 oz. y 6 rs.;"95 "3 tazas de plata, nuevas, obradas de cucharas; una, dorada por dentro y fuera, tiene en el suelo un esmalte de unos ramos con un rótulo de letras; otra con un esmalte de unas tapias azules doradas; y la otra con un escudo dorado hecho de unos estanques y verjas con 3 rótulos de letras; pesaron 4 mar., 7 oz., 2 rs. // - 3 tazas de plata nuevas: una, con 7 bullones grandes en el suelo dorados; otra, con un thesus y un sol en el suelo, todo dorado; otra, con un rótulo de letras todo dorado; pesaron 5 mar., 1 oz., 5 rs. // • lámpara de plata nueva, con 3 cadenas y con 3 rótulos de letras por medio, todo dorado; pesó 3 mar., 6 y $1 / 2$ rs.;" "96 y la "Caldereta de plata nueva con su asa retorcida, con 4 rótulos dorados, con letras por medio y con dos esmaltes en que están dos corderos; pesaron 3 mar., 4 oz., 2 rs." "97 Otro ejemplo lo constituye el capacete hoy conservado en el Kunsthistorisches Museum de Viena (Hofjagd und Rüstkammer, núm. A 645), que parece perteneció a Fernando el
89. Cf. Ara Gil (1977, p. 387, lámina 233).

90. Santillana (1991, p. 288 , v. 126-128).

91. Ferrandis (1943, p. 12) 92. Ferrandis (Ibid., passim). 93. Ferrandis (Ibid., p. 19).

94. Crooke y Navarrot (1898, p. 213-214).

95. Ladero Quesada; Cantera Montenegro (2004, p. 336).

96. Ladero Quesada; Cantera Montenegro (Ibid., p. 337).

97. Ladero Quesada; Cantera Montenegro (Ibid., p. 341). 
98. Fotos y descripción de catálogo en Levenson (1991, p. 158-159).

99. Marcuello (op. cit, fols. 1v, 34v, 128v, 131v).

100. Marcuello (Ibid., fols. $7 \mathrm{v}, 39 \mathrm{v})$.

101. Triste... (1982, p. 15).

102. San Pedro (1973, p. 91).

103. Scrivá (1983, p. 14 y p. 15-16).

104. Dutton (op. cit., vol. 2, p. 314, v. 6-8).

105. Véase la edición y estudio en Isidoro de Sevilla (2000).
Católico. En la banda de este capacete que rodea la base de la calva aparece inscrita la frase "in hoc signo vincit," que hace clara referencia a la cruz que corona el capacete y a la que remata la banda en su parte frontal. Esta cruz aparece intercalada en la palabra "signo," entre las letras " $g$ " $y$ " $n$," imitando las prácticas escriturarias por las que se dibujaba una cruz (+) en el documento que la nombraba, siendo en ambos casos el valor de la cruz tanto táctil como visual. La banda se encuentra además rematada por sendos emblemas coronados de Granada en los centros frontal y posterior. De este modo, el texto, que refiere claramente a la cruz que remata el capacete y a la que lo puntúa en la banda, alude además a la victoria ya obtenida sobre Granada a la vez que sugiere futuras victorias bajo el signo/signum cristiano. ${ }^{98}$ De aquí pueden trazarse nuevas continuidades gráficas entre objetos y cancioneros, ya que los mismos elementos iconográficos aparecen también en el Cancionero de Pedro Marcuello, donde en diversos lugares se encuentran la cruz ${ }^{99}$ ly en manos de figuras religiosas en otros folios) y la granada. ${ }^{100}$ Estos casos muestran cómo la combinación de letras con la ilustración o figura cuyo significado enriquecían se multiplicaba en asociación con el objeto que servía a ambas de soporte material.

De igual relevancia es la inscripción poética de edificios que viene muchas veces incorporada arquitectónicamente a los mismos, a diferencia del papel colgado que dota de significado específico a un elemento arquitectónico como se ha visto en el caso del poema central del libro de Álvarez Gato antes comentado. En estos casos, el edificio proporciona el estímulo visual al poema, tanto en su totalidad cuanto en los elementos pictóricos o artísticos que lo acompañan. En Triste deleytaçión aparece un "mote" de ocho versos escrito "en lo alto del quicial" de una puerta de la que continuamente salen llamas de fuego. ${ }^{101}$ En el Tractado de amores de Arnalte y Lucenda, aparecen tres rótulos blancos y en ellos tres versos escritos en negro ("letras negras") encima de la puerta de una casa. ${ }^{102}$ En Veneris tribunal de Ludovico Scrivá hay letras y versos alusivos inscritos en puertas y en el tribunal de mármol. ${ }^{103}$ El largo Razonamiento - Vergel de pensamiento de Alfonso Enríquez (ID000 1, MN54) se abre con la lectura de una "escriptura" que estaba "escripta por sotil arte" "en una piedra muy dura" que explica el sentido de la edificación. ${ }^{104}$ Que la mención de inscripciones alusivas en verso en los textos de la época no es una mera estrategia retórica viene constatado por la evidencia que proporcionan edificios y construcciones contemporáneos. La unión de poema, representación pictórica y edificio tiene una antigua tradición de cuyos representantes más señeros pueden destacarse los tituli escritos en dísticos elegíacos atribuidos a Isidoro de Sevilla que habrían sido inscritos en la biblioteca, la botica, la especiería y el scriptorium. ${ }^{105}$ 
Las referencias literarias tienen su correlación en las que evidencian las muestras conservadas de edificios de la época. La realeza se sirvió de diversas estructuras arquitectónicas como soportes textuales propios, tal y como se ve en San Juan de los Reyes de Toledo o en otros edificios como el Palacio de la Aljafería de Zaragoza. ${ }^{106}$ Entre los eclesiásticos puede mencionarse el caso de Fray Alfonso de Burgos, quien cubrió los muros de los diversos edificios que mandó construir con sus armas, retratos e inscripciones personales, así como con el escudo y divisas de los Reyes Católicos, todo ello destinado a su engrandecimiento personal. ${ }^{107}$ En la Sala dos Brasões del palacio de Sintra se encuentran cuatro versos escritos alrededor del techo subrayando gráficamente las armas y los apellidos de las familias nobles más importantes bajo el reinado de Manuel I organizados en orden de importancia descendente y sosteniendo la base de la gran bóveda en cuyo centro aparecen las armas de los hijos e hijas del rey Manuel y las del mismo rey en el centro y parte más elevada. La metáfora arquitectónica absolutista se construye, de modo muy significativo, como la unión de signos visuales en forma de ciervos que portan al cuello los escudos de armas de la nobleza manuelina y las correspondientes cimeras en su cornamenta. El apellido familiar aparece escrito en listones blancos que ondean alrededor de sus varas. Los cuatro versos, escritos en neto estilo cancioneril rodean esta estructura aristocrática: "Pois com esforços leais / serviços foram ganhadas / com estas e outras tais / devem de ser conservadas." 08 La estancia abovedada se transforma así en un gran poema ilustrado que pende sobre las cabezas de sus ocupantes, del mismo modo que pende el poder político al que aluden. La "poética ilustrada" así constituida amplía las conexiones con el discurso cancioneril y evidencia la correlación en uso de la poesía como discurso de inscripción cultural pública. ${ }^{109}$ Otro ejemplo puede verse en el castillo de Astorga de Álvar Pérez de Osorio, marqués de Astorga. Este castillo tenía los versos "Donde sus armas posieron, / movellas jamás podieron" debajo del gran escudo que ornaba el centro superior de la fachada. ${ }^{110}$ Del mismo modo se hallaba escrito un poema de Gómez Manrique en la pared de la escalera de las Casas Consistoriales de Toledo, ciudad de la que era corregidor. El poema aparece acompañado del escudo del poeta formando junto con el edificio un macro-signo que depende del contexto material en el que se inscribe y que apunta a su soporte arquitectónico:
106. Yarza Luaces (2005, op. cit.).

107. Hernández Redondo (2001, esp. p. 425-431); Ara Gil (1977, p. 222-262); Ara Gil (1999, p. 322-329).

108. Transcritos en Freire (1973, vol. 1, p. 39).

109. Sobre los usos de la arquitectura en la propaganda política de la monarquía manuelina, véase Pereira (2001). García Lobo; Martín López (1996) han estudiado el valor publicitario de las inscripciones en edificios públicos. Para el entorno monástico puede consultarse Martín López (2016).

110. Sobre este castillo puede consultarse Álvarez de la Braña (1872); Gaya Nuño (1961, p. 229-231); Yarza Luaces (1993, p. 229).

\footnotetext{
Nobles, discretos varones

que gobernais a Toledo,

en aquestos escalones

desechad las aficiones,
} 
111. Manrique (1991, vol. I, p. xxvi, xxxvii; vol. II, p. 318-319).

112. Dutton (op. cit., vol. 2, p. 464 , v. 34-35).

113. En el manuscrito MP3 de las poesías de Gómez Manrique (Biblioteca Real, Ms. II-1250) aparecen escritos en filacterias los versos "No puede templar cordura lo que destempla ventura," entre orlas, sistros o cabezas de laúd y el escudo de doña Leonor de Castilla. En el Misal del Infantado que guarda la Biblioteca Nacional de Madrid (Vit. 18-5) aparecen las armas y lema de la casa del Infantado en filacterias que también aparecen en el Misal rico de Cisneros (BNM Mss. 1540-1546) con los versos: "Pues este fin a de aver la mas sobida ventura, de buscar es lo que dura." Sobre las miniaturas del Misal del Infantado y las del Misal rico de Cisneros debe consultarse Muntada Torrellas 1987 y 1992 respectivamente. Existen muchos otros ejemplos de versos en miniaturas de códices. En la traducción de las obras de Séneca del manuscrito 201 de la Biblioteca General Universitaria de Salamanca traducción de Alonso de Cartagena aparece el comitente (fol. 4v) arrodillado ante una imagen de la Virgen con un libro abierto sobre un almohadón y sus armas y cimera en la esquina inferior derecha. De la mano del comitente sale un largo rollo en el que están inscritos los versos: "De mi vevir a ti servir" (foto y breve descripción en Yarza Luaces [2003], p. 300-301). Sobre los graffiti y la textualización del espacio público, pueden verse los estudios publicados por Casanovas (2002); Cavallo (1997); Fleming (2001).

114. Gimeno Blay; Palasí Fas (1986, Fas 51). codicias, amor y miedo.

Por los comunes provechos

dexad los particulares:

pues vos fizo Dios pilares

de tan riquísimos techos,

estad firmes y derechos. ${ }^{11}$

Los escalones de este edificio proporcionan el estímulo visual para el poema y juntos forman un segundo macro-signo, de modo que el texto inscrito en su soporte arquitectónico genera una metáfora de la gestión municipal. Pero Gómez Manrique no se conformaba con inscribir edificios públicos para crear signos de orden político. En su "carta de amores," "A ti señora de quien" (ID3327), el poeta admite haber escrito graffiti: "escrivo por las paredes / por mote 'verdad e fe.'"112 Este mote es diferente del que aparece inscrito en el escudo que decora su cancionero: "No puede templar cordura / lo que destempla ventura," que a su vez enlaza con versos similares que acompañan igualmente escudos en miniaturas de manuscritos. ${ }^{113}$ La tentación de escribir en las paredes parece haber ejercido un fuerte atractivo para los profesionales o los asiduos de la pluma, pues el notario Pere Seriol escribió mensajes expresando sus anhelos amorosos en las paredes de las calles por donde pasaba su amada, la "gentil, dolsa i amorosa Na Miqueleta," de los que dejó constancia en su registro notarial. ${ }^{114}$ Posteriormente y en alusión a la misma práctica Diego de Leiva se despedirá renegando del amor y prometiendo "ni escribir zien mill vorrones / en las paredes de olvido." 115

Unos usos similares aparecen reflejados en representaciones pictóricas de estructuras arquitectónicas cuya clave simbólica, alusiva a las figuras que aparecen en la escena, viene dada por el texto. Un ejemplo puede verse en la miniatura del fol. 54v del Cancionero de Pedro Marcuello, donde aparece plasmado el acto de presentación del cancionero ante la reina Isabel por parte de su autor y donde puede observarse la inscripción del friso que recorre la parte superior de la pared que sirve de fondo y que lee: "AVE GRATIA PLE.. DOMINVS TECVM." La referencia a la anunciación no consta solo en este letrero, que obviamente identifica a la reina con María, sino que, siguiendo la clave contenida en la inscripción del friso y disponiendo la escena según la iconografía de la anunciación, el mismo Marcuello desempeña el papel del Arcángel San Gabriel, portando la nueva que contiene su libro, en el cual se encuentra escrito el destino divino de su receptora, cuyo papel mesiánico viene desgranado con reiterado énfasis a lo largo del cancionero, que así se revela como depositario de una profecía sagrada. En una miniatura del 
mismo cancionero y en clara referencia a la guerra de Granada, la reina aparece bajo una tienda de campaña, rematada en su parte superior por los anagramas de Cristo y María. Aparecen también en este cancionero inscripciones murales alusivas, aunque con otros matices, en otra miniatura en la que aparecen doña Juana y don Felipe, donde la pared está adornada con un friso con las palabras "AMOR REGINA," en alusión patente a la joven reina. ${ }^{116}$

Frisos similares pueden encontrarse en la arquitectura funeraria de la época, entre cuyos ejemplos puede citarse el Monasterio de San Juan de los Reyes de Toledo, patrocinado por la reina Isabel y destinado a convertirse en panteón real, o el de don Gonzalo de Illescas, oidor de la Chancillería, y su mujer Marina de Estrada, quienes mandaron construir la capilla de San Juan Bautista de la iglesia de El Salvador Valladolid, antes aludida, a finales del XV con una larga e informativa inscripción que rodea las paredes de la capilla. ${ }^{117}$ Estas prácticas remiten a menciones similares de versos escritos en piedra, de uso común en un contexto funerario, tal y como se ha visto en los casos de Álvarez Gato y Gil Vicente. Asimismo, en su Testamento de amores (96JE, ID4456) Juan del Encina manda ser enterrado con un rótulo grabado en verso:
$Y$ mando ser sepultado

vestido de pensamiento

en vn triste monumento

deste rotulo bordado:

Aqui yaze el desdichado

que dexo biva la fe

amador mas desamado

servidor mas olvidado

que en el mundo nunca fue. ${ }^{118}$
115. Recogido en el Cartapacio... (1989, p. 29, v. 19-20).

116. Marcuello (op. cit., p. 14).

117. Ara Gil (1977, p. 334 n. 279).

118. Dutton (op. cit., vol. 5 , p. 39, v. 119-127).

119. López de Gómara (1932, p. 47).

120. Colón (1947, p. 332333).

Dos octosílabos ornaron el escudo de armas que fue concedido a Cristóbal Colón ("Por Castilla y por León / Nuevo Mundo halló Colón"), según Francisco López de Gómara. ${ }^{11}$ Una versión ligeramente diferente da Hernando Colón de los versos que el rey mandó poner como epitafio en la tumba del Almirante l"A Castilla y a León / nuevo mundo dio Colón"). ${ }^{120}$ Del mismo modo, Gómez Manrique escribe letras para sepulturas, tales como la "Letra de la sepultura de hetor" (MP2, ID 1875). El poeta Juan Agraz promete a Juan Marmolejo poner en su tumba el 
121. Dutton (op. cit., vol. 4 , p. 277 , v. $7-8)$.

122. Rodríguez del Padrón (1976, p. 101-102).

123. Libro (1988, p. 201).

124. Para este epitafio, véase Domínguez Sánchez (2010). siguiente "pethafio" alusivo al desmedido gusto de Marmolejo por el vino: "el mayor borracho çafio / de castilla \& de aragon" (SA 1 Ob, ID 1 867)'21 y son letras las que bordean los sepulcros de Ardanlier y Liesa en Siervo libre de amor de Rodríguez del Padrón. ${ }^{122}$ Epitafios en verso aparecen ya en el Libro de Alexandre, donde el sepulcro de Aquiles se encuentra "todo de buenos viersos en derredor orlado." El "pitafio" son cuatro versos en cuaderna vía versificados por un "omne bien letrado" que "puso grant razón en poco de dictado." 123 Un epitafio en cuaderna vía fechado en 1350 y perteneciente a Sancho Sánchez Dávila, obispo de Ávila, se ha conservado inscrito en el muro norte interior del antiguo Monasterio de Santa Ana de Ávila. Está escrito en letra gótica mayúscula del siglo XIV de $5 \mathrm{~cm}$. de altura. ${ }^{124}$

Los casos aquí expuestos muestran las diversas vías de unión de texto y soporte material en objetos personales y edificios públicos, a los que el proceso de inscripción gráfica dota de riqueza significativa. En virtud de su unión material en un soporte compartido, los poemas subliman los objetos inanimados y los elevan a la esfera de lo simbólico. Mediante este proceso, el texto fija el significado del objeto a la vez que llama la atención sobre sí mismo y sobre su autor, inscribiendo la cultura material y dotando de significado a soportes metálicos, textiles o minerales con la ayuda de una escritura que también enlaza con el papel y el libro. Se pone así de manifiesto la naturaleza plástica de la poesía, vehículo de inscripción del mundo material que le sirve de soporte gráfico y al que dota de significado creando un rico universo significativo sustentado por múltiples macro-signos. De este modo, se crea una compleja red intertextual que va desde el papel poético al libro y, al mismo tiempo, a objetos diversos y espacios públicos. La habilidad del poeta de conferir significado al mundo material que lo rodea por medio de su escritura y sublimarlo le permite transformar ese mundo en un vasto soporte textual y en un cancionero propio. 


\section{REFERENCIAS}

FUENTES IMPRESAS

CAMINHA, Pedro de Andrade. Poesias inéditas. Edição Joseph Priebsch. Lisboa: Imprensa Nacional-Casa da Moeda, 1989. Ed. fac-sim.

CANCIONERO de Juan Alfonso de Baena. Edição Brian Dutton; Joaquín González Cuenca. Madrid: Visor, 1993.

CARTAPACIO de Francisco Morán de la Estrella. Edição Ralph A. DiFranco et al. Madrid: Patrimonio Nacional, 1989.

COLÓN, Hernando. Vida del almirante don Cristóbal Colón. Edição Ramón Iglesia. México: Fondo de Cultura Económica, 1947.

CROOKE y NAVARROT, Juan Bautista. Catálogo bistórico-descriptivo de la Real armería de Madrid. Madrid: Fototipias de Hauser y Menet, 1898.

DELICADO, Francisco. Retrato de la Lozana andaluza. Edição Claude Allaigre. Madrid: Cátedra, 1994.

DUTTON, Brian (ed.). El cancionero del siglo XV, c. 1360-1520. Salamanca: Universidad de Salamanca, 1990-1991. 7. v.

FERNÁNDEZ DE OVIEDO Y VALDÉS, Gonzalo. Batallas y quinquagenas. Edição Juan Bautista Avalle-Arce. Salamanca: Diputación de Salamanca, 1989.

FERNÁNDEZ DE OVIEDO Y VALDÉS, Gonzalo. Batallas y quinquagenas (1535-56). Vol. 1. Edição Juan Pérez de Tudela y Bueso. Madrid: Real Academia de la Historia, 2008.

FERRANDIS, José (ed.). Inventarios reales (Juan II a Juana la Loca). Madrid: CSIC, Instituto Diego Velázquez, 1943.

FLORES, Juan de. Grimalte y Gradisa. Edição Carmen Parrilla García. Santiago de Compostela: Universidade de Santiago de Compostela, 1988. 
ISIDORO DE SEVILLA. Isidori Hispalensis Versus. Edição José María Sánchez Martín. Turnhout: Brepols, 2000.

JIMÉNEZ, Juan Ramón. Eternidades. Ed. Víctor García de la Concha. Madrid: Taurus, 1982.

LIBRO de Alexandre. Edição Jesús Cañas. Madrid: Cátedra, 1988.

LÓPEZ DE GÓMARA, Francisco. Historia general de las Indias. Vol. 1. Madrid: Espasa-Calpe, 1932.

MANRIQUE, Gómez. Cancionero. Edição Antonio Paz y Meliá. Palencia: Diputación Provincial de Palencia, Departamento de Cultura, 1991. 2. v.

MARCUELLO, Pedro. Cancionero. Edição José Manuel Blecua. Zaragoza: Institución Fernando el Católico, 1987.

NUÑEZ, Nicolas. Cárcel de amor. In: WHINNOM, Keith (ed.). Dos opúsculos isabelinos: La coronación de la señora Gracisla. Exeter: University of Exeter, 1979.

RESENDE, Garcia de. Chronica de el-rei D. João II. In: Livro das obras de Garcia de Resende. Edição Evelina Verdelho. Lisboa: Fundação Calouste Gulbenkian, Serviço de Educação, 1994.

RODRÍGUEZ DEL PADRÓN, Juan. Siervo libre de amor. Edição Antonio Prieto. Madrid: Castalia, 1976.

SAN PEDRO, Diego de. Tractado de amores de Arnalte y Lucenda y Sermón. Edição Keith Whinnom. Madrid: Castalia, 1973.

SANTIllanA, Marqués de, Iñigo LÓPEZ DE MENDOZA. Poesías completas. Vol. 2. Edição Miguel Ángel Péres Priego. Madrid: Alhambra, 1991.

SCRIVÁ, Ludovico. Veneris tribunal. Edição Regula Rohland de Langbehn. Exeter: University of Exeter, 1983.

TORRE Y DEL CERRO, Antonio de la; ALSINA, Engracia. Cuentas de Gonzalo de Baeza, tesorero de Isabel la Católica. 2 vols. Madrid: CSIC, 1955, 1956.

TORRE Y DEL CERRO, Antonio de la; ALSINA, Engracia. Testamentaría de Isabel la Católica. Barcelona: Vda. Fidel Rodríguez Ferrán, 1974. 
TRISTE deleytaçión: An Anonymous Fifteentb Century Castilian Romance. Edição E. Michael Gerli. Washington, DC: Georgetown University Press, 1982.

UHAGÓN Y GUARDAMINO, Francisco Rafael de, marqués de Laurencín. Relación de los festines que se celebraron en el Vaticano con motivo de las bodas de Lucrecia Borgia con Don Alonso de Aragón. Madrid: Real Academia de la Historia, 1916.

VICENTE, Gil. Copilaçam de todalas obras de Gil Vicente. Vol. 2. Lisboa: Imprensa NacionalCasa da Moeda, 1983.

WHINNOM, Keith (ed.). Dos opúsculos isabelinos: La coronación de la señora Gracisla. Exeter: University of Exeter, 1979.

LIBROS, ARTÍCULOS Y TESIS

ÁlVAREZ DE LA BRAÑA, Ramón. Restos del castillo de Astorga, demolidos en agosto de 1872. La Ilustración española y americana, Madrid, v. 48, p. 767-768, 1872.

ARA GIL, Clementina Julia. Escultura gótica en Valladolid y su provincia. Valladolid: Institución Cultural Simancas, Excma. Diputación Provincial de Valladolid, 1977.

ARA GIL, Clementina Julia. Las fachadas de San Gregorio y San Pablo de Valladolid en el contexto de la arquitectura europea. In: FREIGANG, Christian, et al. (eds.). La arquitectura gótica en España: Actas del Coloquio de la Carl Justi-Vereinigung y del Seminario de Historia del Arte de la Universidad de Gotinga, Gotinga, del 4 al 6 de febrero de 1994. Frankfurt; Madrid: Vervuert-Iberoamericana, 1999. p. 317-334. Actas.

BARROCA, Mário Jorge. Epigrafia medieval Portuguesa (862-1422). Vol. 1. Lisboa: Fundação Calouste Gulbenkian Fundação para a Ciência, 2000.

BELTRÁN, Rafael. La noria con arcaduces (cimera de Jorge Manrique) y otras doce invenciones poéticas en Tirant lo Blanc. Vol. 1. In: PIÑERO RAMÍREZ, Pedro Manuel (ed.). Dejar hablar a los textos: homenaje a Francisco Márquez Villanueva. Sevilla: Universidad de Sevilla, 2005. p. 135-152.

BERNIS, Carmen. Las miniaturas de El Cancionero de Pedro Marcuello. Archivo español de arte, Madrid, v. 25, p. 1-24, 1952.

BERNIS, Carmen. Trajes y modas en la España de los Reyes Católicos. Vol. 2: Los hombres. Madrid: CSIC Instituto Diego Velázquez, 1979. 
BOUZA ÁlVAREZ, Fernando Jesús. Corre manuscrito: una historia cultural del Siglo de Oro. Madrid: Marcial Pons, 2001.

BOUZA ÁlVAREZ, Fernando Jesús. Palabra e imagen en la Corte: cultura oral y visual de la nobleza en el Siglo de Oro. Madrid: Abada Editores, 2003.

CASANOVAS, Ángels et al. Los graffiti: un patrimonio inédito para el análisis de la historia de las mentalidades. Alcañiz: Taller de Arqueología de Alcañiz, 2002.

CASAS RIGALL, Juan. Invenciones cancioneriles y tradición emblemática: de la sutileza cuatrocentista a la agudeza áurea. In: CACHO, Rodrigo; HOLLOWAY, Anne. Los géneros poéticos del Siglo de Oro: centros y periferias. Woodbridge: Boydell \& Brewer, 2013. p. 85-108.

CASAS RIGALL, Juan. El mote y la invención en la estructura narrativa de Cárcel de Amor. Cancionero General, A Coruña, v. 6, p. 33-61, 2008.

CASTILLO GÓMEZ, Antonio. Entre la pluma y la pared: una historia social de la escritura en los Siglos de Oro. Madrid: Ediciones Akal, 2006.

CAVALLO, Guglielmo. Los graffiti antiguos: entre escritura y lectura. In: GIMENO BLAY, Francisco Miguel; MANDINGORRA LLAVATA, María Luz (coords.). Los muros tienen la palabra: materiales para una historia de los graffiti. València: Universitat de València, 1997. p. 61-72.

DOMÍNGUEZ SÁNCHEZ, Santiago. Las inscripciones góticas de la provincia de Ávila. In: MARTÍN LÓPEZ, Maria Encarnación; GARCÍA LOBO, Vicente (eds.). Las inscripciones góticas. II Coloquio Internacional de Epigrafía Medieval, 2006, León, 2006. León: Corpus Inscriptionum Hispaniae Mediaevalium, 2010. p. 536-538.

EDWARDS, Anthony Stockwell Garfield. Middle English Inscriptional Verse Texts. In: SCATTERGOOD, John; BOFFEY, Julia. Texts and Their Contexts: Papers from the Early Book Society. Dublin: Four Courts Press, 1997. p. 26-43.

FLEMING, Juliet. Graffiti and the Writing Arts of Early Modern England. Philadelphia: University of Pennsylvania Press, 2001.

FREIRE, Anselmo Braamcamp. Brasões da sala de Sintra. 3 vols. Lisboa: Imprensa NacionalCasa da Moeda, 1973.

GARCÍA LOBO, Vicente; María Encarnación MARTÍN LÓPEZ. La escritura publicitaria en la Edad Media: su funcionalidad. Estudios Humanísticos, León, v. 18, p. 125-145, 1996. 
GAYA NUÑO, Juan Antonio. La arquitectura española en sus monumentos desaparecidos. Madrid: Espasa-Calpe, 1961.

GIMENO BLAY, Francisco; PALASÍ FAS, María Teresa. Del negocio y del amor: el diario del mercader Pere Seriol. Saitabi, València, v. 36, p. 37-55, 1986.

GÓMEZ-BRAVO, Ana María. Cantar decires y decir canciones: género y lectura de la poesía cuatrocentista castellana. Bulletin of Hispanic Studies, Liverpool v. 76, p. 169-87, 1999a.

GÓMEZ-BRAVO, Ana María. Retórica y poética en la evolución de los géneros poéticos cuatrocentistas. Rhetorica: A Journal of the History of Rhetoric, Ithaca, v. 17, p. 1-38, $1999 \mathrm{~b}$.

GÓMEZ-BRAVO, Ana María. Textual Agency: Writing Culture and Social Networks in FifteenthCentury Spain. Toronto: University of Toronto Press, 2013.

GÓMEZ-BRAVO, Ana María. Vida en fragmentos: el libro de Juan Álvarez Gato y la memoria autobiográfica. Romance Quarterly, Londres, v. 58, p. 231-248, 2011.

HERNÁNDEZ REDONDO, José Ignacio. Aportaciones al estudio del legado artístico de Fray Alonso de Burgos. In: MELERO MONEO, María Luisa et al. (eds.). Imágenes y promotores en el arte medieval: Miscelánea en homenaje a Joaquín Yarza Luaces. Bellaterra: Universitat Autònoma de Barcelona, 2001. p. 423-439.

LADERO QUESADA, Miguel Ángel; CANTERA MONTENEGRO, Margarita. El tesoro de Enrique IV en el alcázar de Segovia 1465-1475. Historia. Instituciones. Documentos, Sevilla, v. 31, p. 307-352, 2004.

LEVENSON, Jay A. (ed.). Circa 1492: Art in the Age of Exploration. New Haven; London: Yale University Press, 1991.

MÁRQUEZ VILLANUEVA, Francisco. Investigaciones sobre Juan Álvarez Gato: contribución al conocimiento de la literatura castellana del siglo XV. Madrid: S. Aguirre Torre, 1960.

MARTÍN LÓPEZ, María Encarnación. Las inscripciones en el monacato hispano: contexto, mensaje e intencionalidad. In: BALDAQUÍ ESCANDELL, Ramón (ed). Lugares de escritura: el monasterio. Alacant: Universitat d' Alacant, 2016. 153-175.

MARTÍN LÓPEZ, Maria Encarnación; GARCÍA LOBO, Vicente (eds.). Las inscripciones góticas. II Coloquio Internacional de Epigrafía Medieval, 2006, León, 2006. León: Corpus Inscriptionum Hispaniae Mediaevalium, 2010. 
MENÉNDEZ Y PELAYO, Marcelino. Orígenes de la novela. Vol 2: Novelas de los siglos XV y XVI. Madrid: Bailly-Ballière, 1907.

MOLINA DE LA TORRE, Francisco J. Los estudios epigráficos desde la teoría de la comunicación: el friso de la Capilla del Colegio de San Gregorio de Valladolid. Documenta E Instrumenta, Madrid, v. 11, p. 141-170, 2013.

MUNTADA TORRELlAS, Anna. Las miniaturas del Misal del Infantado. Boletín del Museo e Instituto Camón Aznar, Zaragoza, v. 38, p. 85-199, 1987.

MUNTADA TORRELLAS, Anna. Misal rico de Cisneros. Madrid: Real Fundación de Toledo, 1992.

OSTOS SALCEDO, Pilar. Escritura distintiva en códices y documentos castellanos de la Baja Edad Media. In: MARTíN LÓPEZ, Maria Encarnación; GARCÍA LOBO, Vicente (eds.). Las inscripciones góticas. II Coloquio Internacional de Epigrafía Medieval, 2006, León, 2006. León: Corpus Inscriptionum Hispaniae Mediaevalium, 2010. 45-63.

PEREIRA, Paulo. Armes divines: La propagande royale, l'architecture manuéline et l'iconologie du pouvoir. Revue de l'Art, Paris, v. 133, p. 47-56, 2001.

PÉREZ PRIEGO, Miguel Ángel. Los Gozos de Nuestra Señora, del Marqués de Santillana. In: ALVAR EZQUERRA, Carlos (ed.). Estudios de literatura medieval en la Península Ibérica. San Millán de la Cogolla: Cilengua, 2015. p. 1061-1072.

PÉREZ PRIEGO, Miguel Ángel. El texto que se hace pintura: Los Gozos de Nuestra Señora, del Marqués de Santillana. In: LABRADOR HERRAIZ, José Julián (ed.). América en Cervantes. Entrega de la Medalla de Oro José Vasconcelos 2013 a Antonio Rey Hazas. México: Frente de Afirmación Hispanista, A. C., 2013. p. 477-492.

PÉREZ PRIEGO, Miguel Ángel. Variantes de imprenta en la poesía del Marqués de Santillana. In: MARTOS, Josep Lluís (ed.). La poesía en la imprenta antigua. Alacant: Publicacions de la Universitat d'Alacant, 2014. p. 159-171.

PETRUCCI, Armando. Public Lettering: Script, Power and Culture. Chicago: University of Chicago Press, 1993.

RÍO NOGUERAS, Alberto del. Libros de caballerías y poesía de cancionero: invenciones y letras de Justadores. In: TORO PASCUA, María Isabel (ed.). III Congreso de la Asociación Hispánica de Literatura Medieval. 1989. Vol. 1. Salamanca: Universidad de Salamanca, 1994. p. 303-318. Actas. 
SILVA MAROTO, Pilar. El Retablo de los Gozos de María de Jorge Inglés. Boletín del Museo del Prado, Madrid v. 30, p. 6-23, 2012.

SIMÓN DÍAZ, José. La literatura mural. Las culturas en la Edad de Oro. Ed. DÍEZ BORQUE, José María. Madrid: Editorial Complutense, 1995. p. 169-179.

TESOROS de la Real Academia de la Historia. Madrid: Real Academia de la Historia, 2001.

WEISS, Julian. Tiempo y materia en la poética de Juan del Encina. In: GUIJARRO CEBALLOS, Javier (ed.). Humanismo y literatura en tiempos de Juan del Encina. Salamanca: Ediciones Universidad de Salamanca, 1999. p. 241-257.

WEISSBERGER, Barbara. Patronage and Politics in the Court of the Catholic Monarchs: The Cancionero de Pedro Marcuello. Studies in Iconography, Kalamazoo, v. 26, p. 175-204, 2005.

YARZA LUACES, Joaquín. Baja Edad Media. Los siglos del Gótico. Madrid: Sílex, 1992.

YARZA LUACES, Joaquín. Isabel La Católica: promotora artística. León: Edilesa, 2005.

YARZA LUACES, Joaquín. La nobleza ante el rey: los grandes linajes castellanos y el arte en el siglo XV. Madrid: Ediciones El Viso, 2003.

YARZA LUACES, Joaquín. Reflexiones sobre la iconografía medieval. Coloquios de iconografía, 26-28 Mayo, 1988, número especial de Cuadernos de arte e iconografía, v. 2, p. 27-46, 1989.

YARZA LUACES, Joaquín. Los Reyes Católicos: paisaje artístico de una monarquía. Madrid: Nerea, 1993

Artículo presentado el 4/4/2020. Aprobado el 25/5/2020.

\section{(cc) BY}

All the contents of this journal, except where otherwise noted, is licensed under a Creative Commons Attribution Licens 